\title{
Risks of Professional Parenting (Original Research)
}

E. Gazikova (Elena Gazikova)1', G. Sebokova (Gabriela Sebokova)1, N. Fellnerova (Nikoleta Fellnerova)', J. Ridosko (Jaroslav Ridosko)²

${ }^{1}$ Constantine the Philosopher University in Nitra, SK

Original Article

${ }^{2}$ University Hospital Trencin, SK

\section{E-mail address:}

egazikova@ukf.sk

\section{Reprint address:}

Elena Gazikova

Department of Social Work and Social Sciences

Faculty of Social Sciences and Health Care

Constantine the Philosopher University in Nitra

Kraskova 1

94974 Nitra

SK

Suource: Clinical Social Work and Health Intervention

Pages: $44-52$

Volume: 8

Issue: 4

\section{Reviewers:}

Andrea Shahum

University of North Carolina at Chapel Hill School of Medicine, USA

Zofia Szarota

Pedagogical University of Cracow, PL

\section{Key words:}

Professional Parenting. Professional Foster Care. Professional Parent. Children's Home.

\section{Publisher:}

International Society of Applied Preventive Medicine i-gap

CSWHI 2017; 8(4): 44 - 52; DOI 10.22359/cswhi_8_4_05 @ 2017 Clinical Social Work and Health Intervention

\section{Abstract:}

Objective: The research aims to identify perceived risks of professional parenting from the viewpoint of professional parents, children's home employees cooperating with professional parents, and Educators. Design: Comparative, quantitative and exploratory research Participants: The research sample consisted of 115 participants - 56 
professional parents, 27 children's home employees and 32 Educators.

Methods: To identify perceived risks of professional parenting, our self-constructed questionnaire containing 32 items describing potential risks of professional parenting was used. These items were assessed by participants using a 5-point Likert Scale.

Results: The results suggested statistically significant differences in perceiving the risks of performing the tasks of professional parenting among children's home employees, professional parents, and Educators.

Conclusion: All the identified results favoured children's home employees and Educators, in the sense that they perceived higher risks in comparison to professional parents. In terms of effect size, observed differences in perceiving the risks from the viewpoint of employees and Educators were small $(\eta=.27-.31)$.

\section{Introduction}

The provision of care to children who are removed from their biological families and placed into children's homes based on a court's order of institutional care or a provisional measure is regulated by the Act No. 305/2005 Coll. on Social and Legal Protection of Children and on Social Guardianship. Currently, it defines a form of provision of care to children in professional families as an option to provide care to a child in a domestic environment of a professional parent who is an employee of a children's home. Child care in a professional family primarily presupposes meeting of a child's individual needs in an environment as close as possible to the model of a family upbringing. The upbringing of a child in an environment where there is no staff rotation and where, instead, the permanent presence of a professional parent is ensured and a child is able to go through a certain period of their life in a family environment has a significant impact on the fulfillment of their psychosocial needs and positively affects their social functioning in their interpersonal relationships later in life (1).

The focus of the present study is on a specific area within the issue being discussed, namely on perceiving the risks of performing the tasks of professional parenting. Specific attention is being paid to comparing risks perceived by professional parents, children's home employees and Educators. As the authors are unaware of any satisfactory empirical starting points for this specific area, the study could be considered an exploratory study introducing the issue in the context of the Slovak Republic.

\section{Methodology and Results}

\section{Research sample}

The research sample consisted of 27 children's home employees, 56 professional parents and 32 Educators.

Of professional parents, 52 were female (92.9\%) and 4 male (7.1\%). 38 professional parents $(67.9 \%)$ completed secondary education with a school-leaving exam, 2 completed first-degree university education $(3.6 \%)$ and $16(28.6 \%)$ completed second-degree university education. As for the marital status, $5(9.1 \%)$ professional parents were single, $36(65.5 \%)$ were married, 6 (10.9\%) lived in a partnership, 7 (12.7\%) were divorced and one professional parent was widowed $(1.8 \%)$. 
There were 26 female and one male children's home employee. As for occupational position, our sample contained 10 Psychologists (37\%), 8 Social Workers (29.6\%), 6 children's home managers $(22.2 \%)$, two Special Pedagogues (7.4\%) and one Assistant Social Pedagogue (3.7\%).

Of Educators, 30 were female and two male. There were 18 (56.3\%) Social Workers, 12 Psychologists (37.5\%) and two reported other positions. 31 Educators worked at the Office of Labor, Social Affairs and Family and only one was an employee of an accredited body.

\section{Research methods}

To identify perceived risks of performing the tasks of professional parenting, our self-constructed questionnaire was used. The questionnaire contains 32 items describing potential risks related to the performance of professional parenting which were assessed by respondents using a 5-point Likert scale (1-not at all risky, 5-completely risky). Risks were assessed by professional parents, children's home employees, and Educators. The questionnaire used enabled a quantitative assessment of perceived risks and an application of comparative analysis of obtained data.

\section{Statistical analysis}

SPSS 21 Software was used to statistically process the results. Descriptive analysis and procedures of statistical inference were employed. With regard to the ordinal level of measurement of examined variables, descriptive statistics were calculated (average order, median and, considering small differences between median values, also average and standard deviation). The Mann-Whitney U Test was used to identify differences in perceiving the risks among groups of respondents. To determine the effect size, a correlation measure was calculated, the values of which were interpreted as follows: $\eta=0.00-0.30$ - small effect, $\eta=0.30-0.50-$ medium effect, $\eta=0.51$ and more - large effect of a difference (2).

\section{Results}

The results pointed out statistically significant differences in perceiving the risks of performing the tasks of professional parenting between children's home employees and professional parents. Significant differences were found in 12 of 32 observed risks of performing the tasks of professional parenting. These 12 areas are shown in Table 1.

All the identified results favored children's home employees and Educators, in the sense that they perceived higher risks in comparison to professional parents. In terms of the effect size, small to medium differences were found $(\eta=.23-.41)$. There were no significant differences between the two groups of respondents in the other 20 risk areas.

Table 1: Perceiving the risks of performing the tasks of professional parenting: a comparison between children's home employees and professional parents.

\begin{tabular}{|l|l|c|c|c|c|c|c|c|c|}
\hline \multicolumn{1}{|c|}{ Issue } & Informant & $\mathbf{n}$ & $\mathbf{m R}$ & $\mathbf{M d}$ & $\mathbf{M}$ & $\mathbf{S D}$ & $\mathbf{U}$ & $\mathbf{p}$ & $\boldsymbol{\eta}$ \\
\hline $\begin{array}{l}\text { Insufficient preparation for } \\
\text { the performance of } \\
\text { professional parenting }\end{array}$ & Employee & 27 & 53.89 & 4 & 4.19 & .92 & & & \\
\cline { 2 - 10 } & $\begin{array}{l}\text { Professional } \\
\text { parent }\end{array}$ & 55 & 35.42 & 3 & 3.07 & 1.41 & 408 & .001 & .38 \\
\hline
\end{tabular}




\begin{tabular}{|c|c|c|c|c|c|c|c|c|c|}
\hline \multirow{2}{*}{$\begin{array}{l}\text { Completed education of } \\
\text { a professional parent in } \\
\text { fields other than human and } \\
\text { social sciences }\end{array}$} & Employee & 27 & 49.70 & 2 & 2.56 & 1.28 & \multirow[b]{2}{*}{521} & \multirow[b]{2}{*}{.022} & \multirow[b]{2}{*}{.26} \\
\hline & $\begin{array}{l}\text { Professional } \\
\text { parent }\end{array}$ & 55 & 37.47 & 2 & 1.89 & 1.01 & & & \\
\hline \multirow{2}{*}{$\begin{array}{l}\text { "Us" vs. "them" distinction } \\
\text { (biological family vs. a child } \\
\text { in a professional family) }\end{array}$} & Employee & 27 & 50.74 & 4 & 3.96 & 0.90 & \multirow[b]{2}{*}{493} & \multirow[b]{2}{*}{.011} & \multirow[b]{2}{*}{.28} \\
\hline & $\begin{array}{l}\text { Professional } \\
\text { parent }\end{array}$ & 55 & 36.96 & 3 & 3.16 & 1.29 & & & \\
\hline \multirow{2}{*}{$\begin{array}{l}\text { Insufficient support from } \\
\text { one's own family }\end{array}$} & Employee & 27 & 49.67 & 4 & 3.93 & $1, .07$ & \multirow[b]{2}{*}{549} & \multirow[b]{2}{*}{.037} & \multirow[b]{2}{*}{.23} \\
\hline & $\begin{array}{l}\text { Professional } \\
\text { parent }\end{array}$ & 56 & 38.30 & 3 & 3.25 & 1.37 & & & \\
\hline \multirow{2}{*}{$\begin{array}{l}\text { Anxiety of a professional } \\
\text { parent }\end{array}$} & Employee & 27 & 53.17 & 4 & 4.33 & 0.68 & \multirow[b]{2}{*}{454.5} & \multirow[b]{2}{*}{.002} & \multirow[b]{2}{*}{.34} \\
\hline & $\begin{array}{l}\text { Professional } \\
\text { parent }\end{array}$ & 56 & 36.62 & 4 & 3.57 & 1.13 & & & \\
\hline \multirow{2}{*}{$\begin{array}{l}\text { Conflict between } \\
\text { a biological child and a child } \\
\text { in a professional family }\end{array}$} & Employee & 27 & 50.80 & 4 & 3.96 & 1.13 & \multirow[b]{2}{*}{518.5} & \multirow[b]{2}{*}{.017} & \multirow[b]{2}{*}{.27} \\
\hline & \begin{tabular}{|l|} 
Professional \\
parent
\end{tabular} & 56 & 37.76 & 3 & 3.30 & 1.22 & & & \\
\hline \multirow{2}{*}{$\begin{array}{l}\text { High demands on a child, } \\
\text { undue expectations on the } \\
\text { part of a professional parent }\end{array}$} & Employee & 27 & 51.19 & 4 & 4.07 & .92 & \multirow[b]{2}{*}{508} & \multirow[b]{2}{*}{.012} & \multirow[b]{2}{*}{.28} \\
\hline & $\begin{array}{l}\text { Professional } \\
\text { parent }\end{array}$ & 56 & 37.57 & 3 & 3.48 & .99 & & & \\
\hline \multirow{2}{*}{$\begin{array}{l}\text { Adopting a child into } \\
\text { a professional family } \\
\text { shortly after losing a child }\end{array}$} & Employee & 27 & 55.13 & 4 & 3.93 & .78 & \multirow[b]{2}{*}{401.5} & \multirow[b]{2}{*}{.000} & \multirow[b]{2}{*}{.40} \\
\hline & $\begin{array}{l}\text { Professional } \\
\text { parent }\end{array}$ & 56 & 35.67 & 3 & 2.89 & 1.34 & & & \\
\hline \multirow{2}{*}{$\begin{array}{l}\text { Adopting a child into } \\
\text { a professional family } \\
\text { shortly after losing } \\
\text { a partner }\end{array}$} & Employee & 27 & 53.63 & 4 & 3.81 & .88 & \multirow[b]{2}{*}{442} & \multirow[b]{2}{*}{.002} & \multirow[b]{2}{*}{.35} \\
\hline & $\begin{array}{l}\text { Professional } \\
\text { parent }\end{array}$ & 56 & 36.39 & 3 & 2.86 & 1.35 & & & \\
\hline \multirow{2}{*}{$\begin{array}{l}\text { Age of a professional parent } \\
\text { under } 25\end{array}$} & Employee & 27 & 53.28 & 4 & 3.63 & 1.11 & & & \\
\hline & $\begin{array}{l}\text { Professional } \\
\text { parent }\end{array}$ & 56 & 36.56 & 3 & 2.69 & 1.29 & 451.5 & .002 & .34 \\
\hline & Employee & 27 & 53.13 & 3 & 2.96 & 1.16 & & & \\
\hline $\begin{array}{l}\text { Age of a professional parent } \\
\text { over } 55\end{array}$ & $\begin{array}{l}\text { Professional } \\
\text { parent }\end{array}$ & 56 & 36.63 & 2 & 2.14 & 1.07 & 455.5 & .002 & .34 \\
\hline Conflicts between & Employee & 27 & 55.78 & 4 & 4.15 & .86 & & & \\
\hline $\begin{array}{l}\text { professional parents and } \\
\text { children in a professional } \\
\text { family }\end{array}$ & $\begin{array}{l}\text { Professional } \\
\text { parent }\end{array}$ & 56 & 35.36 & 3 & 3.13 & 1.18 & 384 & .000 & .41 \\
\hline
\end{tabular}

Notes: mR- mean Rank, Md - median, M - mean, SD - standard deviation, U - Mann-Whitney U Test, $\mathrm{p}$ - significance, $\eta$ - effect size 
The comparison between children's home employees and Educators has shown statistically significant differences in three areas of perceived risks of performing the tasks of professional parenting (Table 2). Children's home employees perceived

"Insufficient preparation for the performance of professional parenting" statistically significantly more risky than Educators. "Adopting a child into a professional family shortly after losing a child" and "after losing a partner" was perceived statistically significantly more risky by Educators in comparison to children's home employees. In terms of effect size, the observed differences were small $(\eta=.27-.31)$. significant differences in perceiving the risks in other 19 areas between the respondents.

\section{Discussion}

Following the results, the most notable differences between professional parents and professional Parenting Educators in perceiving the risks could be observed in three questionnaire items (Table 3).

In terms of effect size, the largest difference $(\eta=.59)$ was found in perceiving the risk of the age of a professional parent over 55. Professional parents perceive the age over 55 as less risky in comparison to

Table 2: Perceiving the risks of performing the tasks of professional parenting: a comparison between children's home employees and Educators.

\begin{tabular}{|c|c|c|c|c|c|c|c|c|c|}
\hline Issue & Informant & $\mathbf{n}$ & mRank & Md & $\mathbf{M}$ & SD & $\mathbf{U}$ & $\mathbf{p}$ & $\eta$ \\
\hline \multirow{2}{*}{$\begin{array}{l}\text { Insufficient preparation } \\
\text { for the performance of } \\
\text { professional parenting }\end{array}$} & Employee & 27 & 34.85 & 4 & 4.19 & .92 & \multirow[b]{2}{*}{301} & \multirow[b]{2}{*}{.037} & \multirow[b]{2}{*}{.27} \\
\hline & Educator & 32 & 25.91 & 4 & 3.66 & .97 & & & \\
\hline \multirow{2}{*}{$\begin{array}{l}\text { Adopting a child into } \\
\text { a professional family } \\
\text { shortly after losing a child }\end{array}$} & Employee & 27 & 24.72 & 4 & 3.93 & .78 & \multirow[b]{2}{*}{289.5} & \multirow[b]{2}{*}{.019} & \multirow[b]{2}{*}{.31} \\
\hline & Educator & 32 & 34.45 & 5 & 4.38 & .79 & & & \\
\hline \multirow{2}{*}{$\begin{array}{l}\text { Adopting a child into } \\
\text { a professional family } \\
\text { shortly after losing a partner }\end{array}$} & Employee & 27 & 25.15 & 4 & 3.81 & .88 & \multirow[b]{2}{*}{301} & \multirow[b]{2}{*}{.034} & \multirow[b]{2}{*}{.28} \\
\hline & Educator & 32 & 34.09 & 4 & 4.28 & .81 & & & \\
\hline
\end{tabular}

Notes: mR- mean Rank, Md - median, M - mean, SD - standard deviation, U - Mann-Whitney $U$ test, $p$ - significance, $\eta$ - effect size

The comparison between Educators and professional parents in perceiving risks pointed out 13 statistically significant differences. Differences favored Educators in all 13 areas - they perceived these 13 areas (Table 3) as more risky in comparison to professional parents. In terms of effect size, differences between Educators and professional parents were medium to large $(\eta=.31$ $.59)$ in ten areas. There were no statistically
Educators (Table 3). There were also professional parents aged over 55 among our respondents. The reason why they didn't consider this item risky could be the fact that a professional parent at this age has rich experience in the area of parenting and, in many cases, also their own adult children who are already relatively independent. Hence, they are able to devote themselves to a child in professional care more thoroughly 
and effectively. It is very important for a professional parent to know that the performance of professional substitute care does not consist only of basic knowledge that they had acquired as a parent (3). The age of a professional parent under 25 was also assessed by Educators as risky. The age under
25 is generally considered risky because of insufficient experience in the area of child care. Young people are one of the most disadvantaged and vulnerable; their behavior is often the most challenging. In such cases, professional parents are expected to be able to provide professional care (4).

Table 3: Perceiving the risks of performing the tasks of professional parenting: a comparison between Educators and professional parents.

\begin{tabular}{|c|c|c|c|c|c|c|c|c|c|}
\hline Issue & Informant & $\mathbf{n}$ & mRank & Md & $\mathbf{M}$ & SD & $\mathbf{U}$ & $\mathbf{p}$ & $\eta$ \\
\hline \multirow{2}{*}{$\begin{array}{l}\text { Completed education of } \\
\text { a professional parent in } \\
\text { fields other than human } \\
\text { and social sciences }\end{array}$} & Educator & 32 & 51.53 & 3 & 2.38 & 0.94 & \multirow[b]{2}{*}{639} & \multirow[b]{2}{*}{.025} & \multirow[b]{2}{*}{.24} \\
\hline & $\begin{array}{l}\text { Professional } \\
\text { parent }\end{array}$ & 55 & 39.62 & 2 & 1.89 & 1.01 & & & \\
\hline \multirow{2}{*}{$\begin{array}{l}\text { Inappropriate treatment } \\
\text { of a child on the part of } \\
\text { a professional parent }\end{array}$} & Educator & 32 & 55.59 & 5 & 4.47 & 0.88 & \multirow[b]{2}{*}{541} & \multirow[b]{2}{*}{.001} & \multirow[b]{2}{*}{.35} \\
\hline & $\begin{array}{l}\text { Professional } \\
\text { parent }\end{array}$ & 55 & 38.16 & 4 & 3.59 & 1.29 & & & \\
\hline \multirow{2}{*}{$\begin{array}{l}\text { "Us" vs. "them" } \\
\text { distinction (biological } \\
\text { family vs. a child in } \\
\text { a professional family) }\end{array}$} & Educator & 32 & 54.95 & 4 & 4.06 & 1.01 & \multirow[b]{2}{*}{529.5} & \multirow[b]{2}{*}{.001} & \multirow[b]{2}{*}{.34} \\
\hline & $\begin{array}{l}\text { Professional } \\
\text { parent }\end{array}$ & 55 & 37.63 & 3 & 3.16 & 1.29 & & & \\
\hline \multirow{2}{*}{$\begin{array}{l}\text { A large age difference } \\
\text { between children in } \\
\text { a professional family }\end{array}$} & Educator & 32 & 55.83 & 3 & 3.16 & 0.88 & \multirow[b]{2}{*}{533.5} & \multirow[b]{2}{*}{.001} & \multirow[b]{2}{*}{.35} \\
\hline & $\begin{array}{l}\text { Professional } \\
\text { parent }\end{array}$ & 55 & 38.03 & 2 & 2.30 & 1.17 & & & \\
\hline \multirow{2}{*}{$\begin{array}{l}\text { Anxiety of a professional } \\
\text { parent }\end{array}$} & Educator & 32 & 52 & 4 & 4.09 & 0.89 & \multirow[b]{2}{*}{565} & \multirow[b]{2}{*}{.030} & \multirow[b]{2}{*}{.23} \\
\hline & $\begin{array}{l}\text { Professional } \\
\text { parent }\end{array}$ & 55 & 40.21 & 4 & 3.57 & 1.13 & & & \\
\hline \multirow{2}{*}{$\begin{array}{l}\text { Conflict between a } \\
\text { biological child and } \\
\text { a child in a professional } \\
\text { family }\end{array}$} & Educator & 32 & 52.83 & 4 & 3.94 & 0.88 & \multirow[b]{2}{*}{629.5} & \multirow[b]{2}{*}{.016} & \multirow[b]{2}{*}{.26} \\
\hline & $\begin{array}{l}\text { Professional } \\
\text { parent }\end{array}$ & 55 & 39.74 & 3 & 3.30 & 1.22 & & & \\
\hline \multirow{2}{*}{$\begin{array}{l}\text { Child of different } \\
\text { ethnicity }\end{array}$} & Educator & 32 & 54.24 & 3 & 3.03 & 0.84 & \multirow[b]{2}{*}{550.5} & \multirow[b]{2}{*}{.004} & \multirow[b]{2}{*}{.31} \\
\hline & $\begin{array}{l}\text { Professional } \\
\text { parent }\end{array}$ & 55 & 38.33 & 2 & 2.35 & 1.24 & & & \\
\hline \multirow{2}{*}{$\begin{array}{l}\text { High demands on a child, } \\
\text { undue expectations on } \\
\text { the part of a professional } \\
\text { parent }\end{array}$} & Educator & 32 & 57.50 & 4 & 4.28 & 0.63 & \multirow[b]{2}{*}{480} & \multirow[b]{2}{*}{.000} & \multirow[b]{2}{*}{.41} \\
\hline & $\begin{array}{l}\text { Professional } \\
\text { parent }\end{array}$ & 55 & 37.07 & 3 & 3.48 & 0.99 & & & \\
\hline \multirow{2}{*}{$\begin{array}{l}\text { Adopting a child into } \\
\text { a professional family } \\
\text { shortly after losing a child }\end{array}$} & Educator & 32 & 61.84 & 5 & 4.38 & 0.79 & \multirow[b]{2}{*}{341} & \multirow[b]{2}{*}{.000} & \\
\hline & $\begin{array}{l}\text { Professional } \\
\text { parent }\end{array}$ & 55 & 34.59 & 3 & 2.89 & 1.34 & & & .54 \\
\hline
\end{tabular}




\begin{tabular}{|c|c|c|c|c|c|c|c|c|c|}
\hline \multirow{2}{*}{$\begin{array}{l}\text { Adopting a child into } \\
\text { a professional family } \\
\text { shortly after losing } \\
\text { a partner }\end{array}$} & Educator & 32 & 61.33 & 4 & 4.28 & 0.81 & \multirow[b]{2}{*}{357.5} & \multirow[b]{2}{*}{.000} & \multirow[b]{2}{*}{.52} \\
\hline & $\begin{array}{l}\text { Professional } \\
\text { parent }\end{array}$ & 55 & 34.88 & 3 & 2.86 & 1.35 & & & \\
\hline \multirow{2}{*}{$\begin{array}{l}\text { Age of a professional } \\
\text { parent under } 25\end{array}$} & Educator & 32 & 56.55 & 4 & 3.66 & 0.94 & \multirow[b]{2}{*}{510.5} & \multirow[b]{2}{*}{.001} & \multirow[b]{2}{*}{.37} \\
\hline & $\begin{array}{l}\text { Professional } \\
\text { parent }\end{array}$ & 55 & 37.62 & 3 & 2.69 & 1.29 & & & \\
\hline \multirow{2}{*}{$\begin{array}{l}\text { Age of a professional } \\
\text { parent over } 55\end{array}$} & Educator & 32 & 63.45 & 3.5 & 3.59 & 0.84 & \multirow[b]{2}{*}{289.5} & \multirow[b]{2}{*}{.000} & \multirow[b]{2}{*}{.59} \\
\hline & $\begin{array}{l}\text { Professional } \\
\text { parent }\end{array}$ & 55 & 33.67 & 2 & 2.14 & 1.07 & & & \\
\hline \multirow{2}{*}{$\begin{array}{l}\text { Conflicts between } \\
\text { professional parents and } \\
\text { children in a professional } \\
\text { family }\end{array}$} & Educator & 32 & 55.50 & 4 & 3.94 & 0.91 & \multirow[b]{2}{*}{544} & \multirow[b]{2}{*}{.002} & \multirow[b]{2}{*}{.34} \\
\hline & $\begin{array}{l}\text { Professional } \\
\text { parent }\end{array}$ & 55 & 38.21 & 3 & 3.13 & 1.18 & & & \\
\hline
\end{tabular}

Notes: mR- mean Rank, Md - median, M - mean, SD - standard deviation, U - Mann-Whitney $U$ Test, $\mathrm{p}$ - significance, $\eta$ - effect size

Another large difference in terms of effect size was the perception of

adopting a child into a professional family shortly after losing a child $(\eta=.54)$ and of

adopting a child into a professional family shortly after losing a partner $(\eta=.52)$.

Professional parents perceived both areas as less risky than Educators (Table 3). In such cases, it is important for Educators to assess the interest and motivation of a person to perform professional care. If the desire to compensate for the loss of a close person primarily prevailed the main purpose of performing the tasks of professional parenting would disappear. The comparison between children's home employees and Educators has shown statistically significant differences in three areas, with the difference in perception of adopting a child into a professional family shortly after losing a child (Table 2) being the most notable of them.

An interesting finding was related to the perception of risks by professional parents and Educators in the case of "Us vs. them" distinction (biological family vs. a child in a professional family) (Table 3 ). One of the main reasons why a child is placed into a professional family is to teach them how a family works. Many children don't have the opportunity to imagine how a "healthy" family works. That is why professional parenting giving a child the opportunity to grow up in an environment that gives them enough incentives for their healthy development and the ability to form new family and social relationships is important. The essence of professional parenting lies in ensuring such a family environment where children can feel accepted (5). It is impossible for a child to feel accepted when making "us vs. them" distinctions, as they perceive differences in the way professional parents bring them up. This area was perceived as less risky by professional parents in comparison to Educators.

This area is closely associated with inappropriate treatment of a child on the part of a professional parent and with high demands on a child, undue expectations on the part of a professional parent (Table 3). It is assumed that a professional parent 
is suitably selected based on their competences and experience, is well prepared for performing the role of a professional parent, and that there are no undiscovered pathological problems in their personality (4).

Perceiving risks by professional parents and children's home employees has shown statistically significant differences in perceiving the risks of performing the tasks of professional parenting. Most interesting were the results regarding perceiving the risk of insufficient preparation for the performance of professional parenting (Table 1). Children's home employees perceived this area as more risky in comparison to professional parents $(\eta=.38)$. Knowledge, experience, and education - a professional parent needs to have all of those to be a true professional and to be able to perform their job in the best possible way (3). Unless a professional parent has sufficient preparation, also other risks may become evident during the performance of the tasks of professional parenting - inappropriate treatment of a child on the part of a professional parent, high demands on a child, undue expectations on the part of a professional parent, conflicts between professional parents and children in a professional family and numerous others.

\section{Conclusion}

All the identified results favored children's home employees and Educators, in the sense that they perceived higher risks in comparison to professional parents. In terms of effect size, observed differences in perceiving the risks from the viewpoint of employees and Educators were small $(\eta=.27-.31)$.

Perceived risks of performing the tasks of professional parenting from the viewpoint of professional parents, children's home employees and Educators overlap to a substantial extent. All three groups reported similar risk areas - adopting a child into a professional family shortly after losing a child; adopting a child into a professional family shortly after losing a partner; the age of a professional parent under 25; the age of a professional parent over 55; "us $v$ s. them" distinction (biological family vs. a child in a professional family); high demands on a child; undue expectations on the part of a professional parent.

\section{References}

1. Act No. 305/2005 Coll. on Social and Legal Protection of Children and on Social Guardianship and on amending and supplementing certain acts.

2. COHEN J (1992) A power primer. In Psychological Bulletin [online] vol.112, no.1 [cit. 2017-11-06]. <http://www.bwgriffin.com/workshop/Sampling\%20A $\% 20$ Cohen\%20tables.pdf $>$ ISSN unknown.

3. KIRTON D (2007) Step forward? Step back? Professionalization of fostering. In Social Work and Social Sciences. ISSN 0953-5225, 2007, vol. 13, p. 6-24.

4. STACE S, LOWE K (2009) Reducing risks for young people in foster care. A UK study: Research report. Brighton UK TSA Publishing Ltd, 2009. 116 p. ISBN 9781871504996.

5. MOJTOVA M, SEDLAROVA K, SRANK M (2013) Clinical Social Worker. Nitra: Constantine the Philosopher University in Nitra, 263 p. ISBN 978-80-558-0269-5.

6. ZELINSKA I (2011) Five myths about professional families. [online], 2011, [cit. 201710-21]. Available at: <http://idazelinska. blog.sme.sk/c/254186/Patmytov-o-profesionalnychrodinach. html?fb_ref=like_clanok_dole_blog \&fb_source=home_onel ine>.

7. COLTON M, SANDERS R, WILLIAMS $\mathrm{M}$ (2011) An introduction to working with children. A guide for social workers. Hampshire: PALGRAVE, 2011. 
8. ORENCAK R, JANICKO M, MACEJOVA,

This contribution was created as part of Z (2015) Osteoarthritis of the knee joint - the VEGA project No. 1/0606/16 Potential the basis for targeted rehabilitation treat- of securing and performance of profesment. In Rehabilitation 3, XLIII(53), ISSN sional parenting.

0375-0922, s. 185-198. 